\title{
Propagation Model and Marketing Strategy Analysis of Network Homemade Drama
}

\author{
He Zichen ${ }^{1,}$,, Yang Fan ${ }^{2, b}$ \\ ${ }^{1,2}$ Chongqing Normal University Institute of media, ChongQing,401331,China \\ ab632431317@qq.com
}

Keywords: Network homemade drama, propagation model, marketing, strategy

\begin{abstract}
This paper uses " 5 W" propagation mode of Harold Dwight Lasswell to analyze elements of propagation model in TV homemade drama and network homemade drama, analyzes characteristics in propagation model between them, and elaborates innovation and timeliness of TV homemade drama and network homemade drama in our country from the perspective of marketing. Through network viral marketing and topic marketing, etc., methods, unique copyright, high-quality resource integration, and extension development of upstream-downstream industries, etc., can be realized in production and issuing process of homemade drama, so as to promote prosperity and development of homemade drama market in our country.
\end{abstract}

\section{Introduction}

New media is the cutting edge of current media development. Video signal is one of the most infectious types in information spreading of new media ${ }^{[1,2,3]}$, while network homemade drama is the latest achievement of video signal development. It is developing at top speed. Although network homemade drama hasn't had a written and widely approved definition so far, researches on it have presented the tendency in recent years. These researches mainly concentrate on regarding it as a kind of newly sprouted thing and studying its characteristics and content level ${ }^{[4,5]}$. Propagation of network drama changes people's habits of watching and breaks through frame system of traditional media in the way of content acquisition, information consumption and funny games, etc. Production of anything is no accident. There must be social and historical reasons. Development and prosperity of anything are not necessary. It must have the meaning of existence and development.

This paper analyzes development process of network drama in our country, confirms current development patterns of network drama, and knows about "myth" of development and prosperity for network drama-deep reasons for developing network drama rapidly and changes brought by development of network drama, through exploration on producing meaning of network drama and excavation on changes of internet culture.

\section{Existing Problems of Network Homemade Drama}

Severe Shortage of Originality for Homogenization Phenomenon for Contents:If network homemade drama wants to break through in market monopoly of traditional teleplay, it must analyze the market of network audiences accurately and carry out precise localization. Main constituent of our netizens present the tendency of becoming younger in average age. Therefore, city, love and career become the main battlefield of numerous network homemade dramas, such as Story of Qian Duoduo's Marriage, Miss Puff, the Love Comes, Online Love, Crazy Office, and Utopia Office, etc., lots of network homemade dramas. These contents mainly concentrate on love and career. The development time of network homemade drama is relatively shorter and still keeps in the stage that needs to be accepted by audiences. It is necessary to have clear orientation. Secondly, by comparing with network homemade drama, variety show is more flexible, has shorter period and can constantly adjust its contents to adapt to requirements of audiences. Meanwhile, variety show is received fewer restrictions of national boundaries and regional cultures. On the other hand, network homemade drama is obviously impacted by local characteristics and cultures. 
The episode that achieves success overseas may be not successful in Chinese shooting. Therefore, how to reinforce originality of network homemade drama, strengthen Chinese characteristics and fabricate China Model is crucial.

Shortage of Mainstream Consciousness and Prominent "Vulgar" Problems:The development of network homemade drama is call as barbarous development. In order to obtain higher audience rating, lots of video websites add a great number of vulgar, spoof or even naked contents in the network homemade drama, which can obtain parts of short-term visible audience rating. As a matter of fact, there is no ground for blame to be "vulgar". Being appropriate "vulgar", on the contrary, can even press close to life of audiences, be accepted by audiences, and also conform to characteristics that network homemade drama presses close to audiences and has lower threshold value. However, lower threshold value doesn't mean lower requirement. Blindly vulgar, spoof or naked actions, on the contrary, will make audiences become disgusted with it and ultimately be abandoned by audiences.

\section{Flooding Product Placement and Obvious Tendency to Consumerism}

The word "Product Placement" appeared in traditional teleplay and cinematographic works at the earliest. Because it will impact viewing effect and feeling of audiences and make audiences produce the consequence of leaping drama, it has been receiving the dispute. For producers, it can be say a kind of earning safeguard, but excessive product placement will make audiences dislike it extremely and run off lots of audiences, so as to make producers sustain losses in business, when broadcasting. On the problem of product placement, there is essential difference between network homemade drama and traditional teleplay. In the episode process of network broadcasting platform, it doesn't make audience get used to accepting advertisements. To be more accurate, the reason for why network platform can attract a large portion of audiences to watch network broadcasting from watching TV platform is because there is no advertisement or has a little spot announcement. From a certain perspective, this is very necessary. However, excessive and flush product placement will greatly influence viewing feeling of audiences and greatly discount their viewing effect, so as to reduce its click rate and go against notification of advertisers' advertisements and achievements of influencing effects. Thus, it is extremely necessary to weigh among contents of network homemade drama, product placement and viewing experience of audiences and well control of a certain degree. This will directly influence follow-up development of network homemade drama.

\section{Unbalanced Single Standard and Urgently Improved Supervision}

Network homemade drama in our country develops rapidly. Barbarous growth rate makes the introduction of policies and regulations can't catch up with. Traditional teleplay has already formed a set of perfect censorship. Before the final broadcasting, teleplay needs to be approved by the State Administration of Radio Film and Television uniformly. Thus, its contents and quality can be safeguarded relatively. The construction of censorship in network homemade drama is not far from enough. The development of network homemade drama needs a set of perfect supervision system, which doesn't mean to limit the development of network homemade drama. On the contrary, this exactly provides a most beneficial safeguard for a good development environment. It is crucial and urgent to how to follow up with the pace of developing network homemade drama, reinforcing corresponding policy supervision and supporting facility.

\section{Propagation Mode of Network Homemade Drama}

The predecessor of network homemade drama is the homemade drama of teleplay. The differences between them lie in production subjects and broadcasting channels. Just as its name implies, two elements of network homemade drama are network and homemade, respectively. Network indicates that it regards computer network as media. Convenience includes lower threshold for playing admittance, content selectivity, direct selectivity and operability, etc. 
Homemade means that network media plan and invest, shoot, produce and play. In a nutshell, "network homemade drama" refers to order by a website uniquely, play by itself, and belong to its own brand, form an alliance, cooperate together, issue together, share benefits together and share risk together by unifying producing and playing. As shown in Figure 1, it displays propagation mode of network homemade drama.

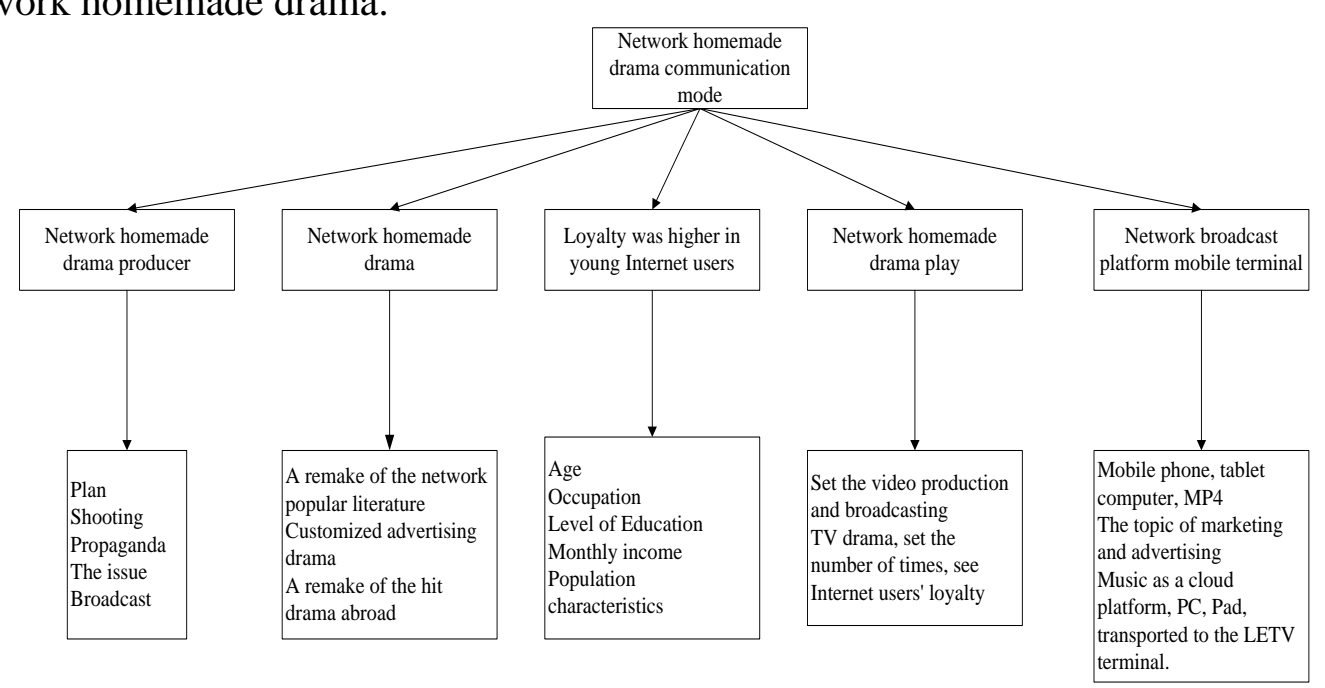

Figure 1 Propagation Mode of Network Homemade Drama

Producers of Network Homemade Drama:From producing to issue, homemade drama needs to experience a complicated input and output process. Topic selection of video websites, conception of scripts, shooting, production and issuing are out of conforming to production process and standard. Websites also can select to invest and shoot together with video production companies, etc., video production institutions. Currently, from the perspective of development experience for ascending to video websites of producing network homemade drama, television mode of cooperative production between website television media and video production companies provides possibility for launching network homemade drama successfully.

The majority of network homemade drama adopts do-it-yourself mode in the whole process, including planning, shooting, publicity, issue and broadcast, etc., all work, and can really realize "self-marketing" and conduct conversion of roles from content distributors to content producer.

Scripts of Network Homemade Drama:Almost all network homemade dramas are printed with the mark of "domestic idol TV series". Compared with television homemade drama, network homemade drama has relatively single types of scripts. However, targeted audiences even more clearly locked in younger and more fashionable young peoples in netizens. Adaptive network best-seller literature, advertising custom-made drama and copying foreign hot broadcast drama are the main scripts of network homemade drama.

Network, etc., Mobile Terminal Broadcasting Platform:Quality and variety of network homemade drama in our country are constantly improving and abundant. Network homework drama with professional hot broadcast and best quality brings audience rating climax and abundant earnings and also is received good graces by TV stations in succession. "Network homemade drama" buys back to television media, further broadens survival market of network homemade drama. Network homemade drama can be successfully bought back to TV stations. The two-way communication of channels formed by "homemade drama" establishes "net platform linkage" and forms win-win situation of network and TV stations.

Young Netizens with Higher Loyalty:By analyzing and summarizing audiences of network homemade drama, we can conclude audiences of network homemade drama, as follows; characteristics of network homemade drama's audiences as shown in Table 1: 
Table 1 Audiences’ Characteristics of Network Homemade Drama

\begin{tabular}{|l|l|}
\hline Age & Between 18-35 years old \\
\hline Profession & Give priority to employees, school students, and freelance \\
\hline Level of education & $\begin{array}{l}\text { Give priority to people with higher education(colleges or above } \\
\text { account for 59\% of the total audiences) }\end{array}$ \\
\hline Monthly income & People with 2000 Yuan of monthly income occupy 48\%. \\
\hline Group characteristics & $\begin{array}{l}\text { People with stronger network cognition, active consuming behavior } \\
\text { and stronger receptivity, etc., characteristics are the social main force } \\
\text { groups that have the largest consumption ability. }\end{array}$ \\
\hline
\end{tabular}

Play Volume of Network Homemade Drama:The advantage of a website that integrates production with broadcasting is to achieve free arrangement. Due to unlimited resources and time, audiences can click the website and watch teleplay, episode and viewing times at anytime anywhere. This attracts a lot of netizens to a great extent and increases loyalty of netizens, so as to improve website click rate and play times of homemade drama. At present, advertisement putting effect of advertisers in a website is mainly measured by depending on hits. The play volume and website clicking volume naturally are received good graces of advertisers, stimulate investment behavior of advertisers, and provide reliable safeguard for profits of video websites.

\section{Marketing Strategy of Network Homemade Drama}

Figure 2 is production process of network teleplay. Production process of websites' TV series is more convenient. Now, if a drama needs to be approved by the State Administration of Radio, Film and Television, it must pass through several months or half a year. Mass broadcasting contents in TV stations make distribution channels of the majority of teleplay become abnormally narrow. Copyright of network homemade drama is similar to copyright ownership of TV station homemade drama and belongs to video websites. Except for enjoying broadcasting in its website, video websites can conduct secondary sales of copyright for homemade drama. For example, after audience rating of the Love Comes broken through 50 million, Tudou sold this copyright to 11 countries and areas. The highest stockpiling was sold to more than 30000 dollars. This indicates that Tudou uses profit new situation of video websites to sell "produced copyright" of network homemade drama.

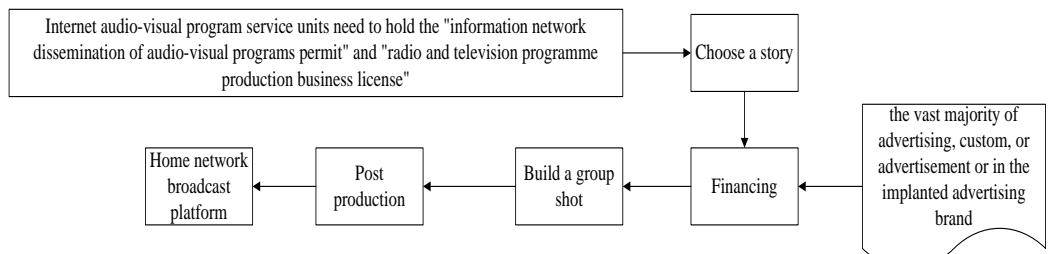

Figure 2 Production Process of Website Teleplay

\section{Television and Network Linkage Buys Back to TV Stations for Increasing Earnings}

After network is broadcasted successfully, homemade drama buys back to TV stations. Television resource information interactive broadcast and excellent repertory cover all groups of television and network and enhance audience rating. Secondly, selling copyright to TV stations can obtain profits of secondary sales. Meanwhile, the same advertisement or column naming, as long as it can obtain old audiences on television, through television and network linkage, a batch of young audiences may be obtained. Advertisers can realize effective supplement on network release through television release.

\section{Forge Homemade Drama for Advertisers and Release more accurate Advertisements}

Internet video advertising is increasing with the $200 \%$ and $300 \%$ every year, while advertisements of televisions have already been hard to increase at such a speed. Nowadays, main 
profit point of network homemade drama in our country mainly comes from product placement, pre-movie adverts, naming and sponsor of network homemade drama, return selling televisions, VIP added-value paid service and website click rate, etc., commercial forms, and adopts pre-roll, rear-mounted and interval product placement. For instance, Sohu implants the advertisement of “Beijing Hyndai Motor" into Story of Qian Duoduo's Marriage of homemade drama, further extends to downstream industry chain, integrates with website resources in all direction, coordinates actors to hype entertainment news, drives spreading of Sohu forum and automobile, etc., modules and forms a pattern of circular economic development. Advertisers customize repertory through website cooperation and integrate creative advertising into plot of teleplay. Through plot presentation, prop, background setting and lines presentation or implied or obvious means, the purpose of advertising brand publicity can be reached, so as to make websites obtain recoverable costs within short time.

This advertisement is customized for advertisers. This can take advantage of ampler resources and reinforce coverage broadcast. Soft advertising that is implanted into plot of homemade drama is more beneficial to be accepted by audiences and impacts consumption custom and consumer psychology of audiences imperceptibly.

\section{Establish Audience Rating Effect, Analyze New Path and Lock Targeted Audiences}

First of all, watching time of audiences should not be limited. They can select many methods, such as online live telecast or rerun at anytime anywhere. Secondly, audiences can select episodes and segments that they like in line with their demands and personal preference. Audiences can select play speed in line with their demand to carry out Fast Forward, Slow Backward and Pause, etc., operations. Through professional streaming media monitoring software, websites can observe where do audiences carry out fast forward and pause, so as to record by background procedure $f$, analyze where is attractive in episodes and which is easily to be ignored by audiences. Thirdly, $M$ website also can judge which kind of terminal should be adopted by audiences in line with audiences' behavior, selecting telephone or IPAD, etc.

\section{“Interact Propagation Mode of Network Homemade Drama to Forge Brand-New "Network Marketing”}

Compared with relatively traditional teleplay, the pattern of "broadcasting in season and broadcasting in shooting" has incomparable advantage of "two-way interactive communication". Websites can set up front and back viewing and discussion areas of broadcasting homemade drama, attract audiences to interact and provide two or more plot development directions and story structure for audiences. Audiences can determine development of a protagonist, or even can view more diversified open plot through different windows in line with their understanding and preference on repertory. My Name's Hao Congming is another hot homemade drama launched by LETV. The ending of every episode sets up net friend video of "drifters in Beijing” and appeals audience to comment interactively. According to statistical result of Boys' Matters monitored by Unotice, 83 websites issue or reprint related contents of Boys' Matters. There are a total of 36051 clicks and 3924 replies. By building topics and reprinting repeatedly, viral marketing is formed.

\section{Multi-Platform Multi-Terminal, Complementary Development of Upstream and Downstream Industry Chains}

Media support with more comprehension, intuition and high efficiency can be realized. By producing and issuing homemade drama, video marketing and entertainment marketing, etc., marketing strategies can be realized. Multilevel and three-dimensional channels of communication can be got through. New era of "multi-platform multi-terminal" marketing can be launched. It is necessary to integrate media with social platform, two-way interaction between ratings and propagation, intersection between fixation and mobile terminal, complementation between 
purchasing and homemade, mutual motivation between competition and cooperation and realize the largest efficient optimization of media resources. Through the website, we can fabricate topics, form hot media coverage, form public opinion by reporting and take shape of viral marketing by using public onions to guide discussion of Microblog and forum.

The industry chain development between network homemade drama and traditional homemade drama has many similarities. With the help of netizens' stickiness, network can attract audiences. By playing episodes on line, online network game, cartoon, film, music and polyphonic ringtone, etc., can be launched. Moreover, we also can establish virtual community and develop mating toys, etc. Thus, ecological circle with sound and sustainable development, including users, content party, advertisers and network video industry, can be formed.

\section{Summary}

In recent years, homemade drama, as a new-type production and marketing mode of coping with market competition, also has added more innovation and effectiveness, clearly divided production platform, broadcasting platform, and marketing channels of teleplay and formed "flow line production”, based on inheriting traditional television marketing strategy and propagation mode. Through group task distribution cooperation of script creation, spot shooting, post production and propagation issuing, etc., in order to ensure respective independence, reduce unnecessary administrative intervention, producers must improve their quality and professional level, and intensify responsibility consciousness of audiences. For increasingly emerging development bottleneck of homemade drama, homemade drama industry in our country must pay attention to policy and market, change marketing mechanism, improve professional level and teams and create more excellent homemade drama.

\section{References}

[1] Claus Brunn Jensen, Media Fusion: Three Dimesion of Network Communication, Mass Communication and Interpersonal Communication, Liu Jun, Shanghai: Fudan University Press, 2012, 14-15.

[2] Kuang Wenbo, Introduction to Network Communications, Beijing: Higher Education Press, 2009, p164-178.

[3] Min Dahong, Outline of Digital Media, Shanghai: Fudan University Press, 2006, p174-185

[4] Li Xiaowei, Nirvana and Rebirth of Television in All Media Era, Press Circles, Vol 14, 2012, 17, p37-43.

[5] Zhao Zhili, Introduction to Internet Communication, Sichuan People’s Publishing House, 2009, p117-118

[6] Chen Xiaowan, Program Form and Development Tendency of Network Homemade Drama, News Amateur, Vol18, 2012, p12-14

[7] Liu Qian and Feng Zhimin, Development at this Stage of Network Homemade Drama, Anhui Literature, Vol 5, 2011, p221-223.

[8] Su Jingyi, Influence Exploration on Video Websites of National Internet Television [J], Journal of Jiangxi Radio and Television University, 2010, p11-14

[9] Ya Nanliang and Xue Lai, Brief Discussion on Innovation and Effectiveness of Homemade Drama Marketing, Vol 7, 2011, p 19-21

[10] Hu Xin, Competitive Media between Homemade drams of Provincial TV Stations, Vol 11, 2009, p49-51 